\title{
Great Britain
}

In its May issue, the International Review devoted an article to the twenty-third award of the Florence Nightingale Medal and reported that this high distinction had been bestowed upon Miss Gwyneth Ceris Jones at the General Assembly of the British Red Cross. Miss Marjorie Houghton, another British recipient, could not be awarded the medal and the diploma at the time because she was not in London. We learn that she received them in British Honduras, where she was acting as Adviser to the local branch of the British Red Cross.

Miss Houghton's services covered a wide field. Suffice it to recall that, during the Second World War, she served in the British Expeditionary Force, in India and Ceylon, after which she held important posts in various hospitals and rendered signal services to the Red Cross in Kenya, Nigeria and Dominica, before going to Botswana as a League of Red Cross Societies delegate.

\section{India}

Last April, the ICRC informed all National Societies about a Plan of Action for the dissemination and development of international humanitarian law applicable in armed conflicts. The Indian Red Cross has responded with a statement regarding the efforts made so far to disseminate the Geneva Conventions in that country. We think this may interest our readers as evidence of the importance and effectiveness of the work carried out by the National Society in this field.

The Indian Red Cross Society has constantly been working for the dissemination of the Red Cross principles and the diffusion of knowledge of the Geneva Conventions in India, through a network of 525 Branches. Articles on these subjects often appear in the Headquarters journals The Red Cross Journal and The Indian Junior, as also in various journals and brochures published by the 


\section{IN THE Red Cross WorLd}

Branches in several Indian languages. Instructions on these are also imparted in the Red Cross Training Camps organized from time to time all over the country for workers and juniors.

Lectures on the Red Cross and the Geneva Conventions are also delivered by an Indian Red Cross Officer specially deputed from Headquarters for the purpose, at Senior Indian Police Service Officers' courses generally held twice a year.

The Society has also distributed a number of copies of the "Course of Five Lessons on the Geneva Conventions" to its Branches and the Ministries of Health and Education. The latter Ministry has forwarded this publication to all State Governments and Universities for including the study of the Conventions in the prescribed programmes of public instruction, both at the primary and secondary stages of education, as also in Universities some of which have already included the study of the Conventions in their curriculum.

Through the Society's efforts, the Government of India has taken the following steps for dissemination of knowledge on the subjects:

1. Publication and wide circulation of a book entitled The Geneva Conventions of August 12, 1949, containing the text of the four Conventions, the instruments of ratification by India, the eleven resolutions of the Diplomatic Conference of 1949, and a list of signatory States and of those States which had acceded to the Conventions up to the time of publication of the book.

2. A pamphlet entitled Notes on the Geneva Conventions 1949 has been published and issued.

3. Service Headquarters have published an order containing a summary and the broad features of the Conventions, for the information of Defence personnel.

4. A small booklet containing a summary of the Conventions has been published and pasted in the pay-books of all Armed Forces personnel.

5. In addition to the dissemination of information concerning the Geneva Conventions among Defence Services personnel, including chaplains, through Army/Navy/Air Force Orders, the study of the Conventions is included in the syllabi of instruction 
of a number of institutions, e.g. Defence Services Staff College, Wellington; Indian Military Academy, Dehra Dun; Officers' Training Service, Armed Forces Medical College, as well as all Nursing Colleges and Nursing Schools in the country.

6. With regard to the dissemination of the text of these Conventions among the personnel of India's contingents, whenever they are required to serve under the auspices of the United Nations, the rights and obligations of the Indian Armed Forces personnel under the Geneva Conventions, along with the question of penal measures to suppress infringements of the Conventions, are brought to their notice. A suitable paragraph of the study of the Conventions is also included in the general instructions issued for the guidance of Indian contingents when posted abroad.

7. Annex I to the Third Convention has been included in the Medical Administrative Instructions of the Armed Forces in respect of medical examination of prisoners of war.

8. Necessary steps have been taken to include the study of the Conventions, in particular of the Fourth Convention, in the course of instructions imparted to the Indian Administrative Service and Indian Police probationers.

9. An effort has been made to disseminate information regarding the Conventions, in so far as they apply to Nursing Services, through distribution of a number of pamphlets on the subject to Nursing Schools and by publishing the relevant articles in the Nursing Journal of India.

Besides the above, necessary action is being taken for the printing of the Indian edition of the School Textbook and Teacher's Manual entitled "The Red Cross and My Country" in order to contribute more actively to the dissemination of the humanitarian principles of the Red Cross and the Geneva Conventions in primary schools. Copies of the "Soldier's Manual" received from the ICRC have also been distributed among the Jawans. Moreover 60,000 copies of the Hindi version of the Manual have been printed for distribution among Defence personnel. 